\title{
CORRELATION BETWEEN PLASMA LEAD AND SERUM ANTI MULLERIAN HORMONE LEVELS IN WOMEN WITH PREMATURE OVARIAN FAILURE
}

\author{
By
}

\author{
Yehia Abd El-Salam Wafa, EL-Sayed Mohammad Taha, Abd El-Raouf \\ Abd El-Raouf Abo Nar and Ateia Ahmad Ateia \\ Departement of Obstetrics and Gynecology, Faculty of Medicine, Al-Azhar University \\ E-mail: drateia4886@yahoo.com , Phone: 01099343373
}

\begin{abstract}
Background: Lead is a highly toxic metal to humans, with the injurious effects on the hemopoietic, nervous and reproductive system. Lead crosses the placenta during pregnancy and has been associated with intrauterine death, prematurity and low birth weight.

Objective: To collate between plasma lead and serum antimullerian hormone levels in women with premature ovarian failure, by estimation of level of Anti Mullerian Hormone (AMH), Follicular Stimulating Hormone (FSH), Estradiol (E2) and plasma Lead level.

Subjects and Method: This study was conducted in Al Azhar University Hospital outpatient clinics after approval of the research and ethical committee during the period from December 2015 to December 2018. Study groups were: Group 1 included 50 normal candidate women under 40 years old has regular menstrual cycles (21-35 days), fertile (at least one natural pregnancy carried to term), and serum FSH was less than 10 $\mathrm{mlU} / \mathrm{ml}$, Group 2 included 50 patients with premature ovarian failure who aged under 40 years with absence of spontaneous menstrual bleeding for more than 12 months, serum estradiol level was less than $25 \mathrm{pg} / \mathrm{ml}$, serum FSH level more than $40 \mathrm{mlU} / \mathrm{ml}$. AMH, plasma lead level in patients with premature ovarian failure diagnosed and correlated with level of serum FSH with the normal control group.

Results: There was a statistically significant positive correlation between plasma lead levels with FSH among the study group. On the other hand, there was no statistically significant correlation between plasma lead level and AMH level.

Conclusion: The anti mullerian hormone showed a significant difference between the cases of premature ovarian insufficiency and the control group. Moreover, AMH was a good marker for ovarian reserve and ovarian response for gonadotropins simulation. Chronic exposures to heavy metals, especially lead, affected the ovarian function and impairment in folliculogenesis which increased the incidence of Premature Ovarian Failure (POF) especially in rural area due to the low socioeconomic status.
\end{abstract}

Key words: Plasma Lead, Anti mullerian Hormone and Premature Ovarian Failure.

\section{INTRODUCTION}

Women with POF suffer from anovulation and hypoestrogenism and present with primary or secondary amenorrhea, infertility, sex steroid deficiency and elevated gonadotrophins (Jankowska, 2017). The condition affects approximately $1 \%$ of women, occurring in $10-28 \%$ of women with primary amenorrhea and $4-18 \%$ in those with secondary amenorrhea (Okeke et al., 2013). A wide spectrum of pathogenic mechanisms may lead to the development of POF including chromosomal, genetic, autoimmune, environmental, and 
iatrogenic causes. In a large proportion of cases, no cause is found, and they are classified as idiopathic or karyotypically normal spontaneous POF (Ebrahimi and Akbari Asbagh, 2011). AMH is useful in fertility assessment, as it provides a guide to ovarian reserve. AMH measurement is the best prognostic marker of the ovarian response to controlled ovarian stimulation during IVF cycles, especially when a single marker is determined (La Marca et al., 2010). Chronic excessive exposure to lead was associated with increase rates of infertility, miscarriages, still birth and poor infant outcomes. Epidemiological and animal studies have illustrated that the potential to disrupt ovarian function. From high to low doses of lead exposure, there are different responses of lead including reduced fertility, spontaneous abortions, low birth weight, impairment in folliculogenesis, and even damage to the ovaries are also reported (Sunil, 2011). Lead is highly toxic to humans, with the injurious effects on the hemopoietic, nervous and reproductive system. Lead crosses the placenta during pregnancy and has been associated with intrauterine death, prematurity and low birth weight (Flora et al., 2011).

\section{PATIENTS AND METHODS}

This an observational cross sectional study conducted in Al -Azhar University Hospital outpatient clinics of Al-Hussien and Bab Al-Sharyah during the period from December 2015 to December 2018. All patients were given informed consents and fully informed about the nature and objective of the clinical study, the potential risks, benefits of study participation and their rights as research subjects. The study included 100 women divided into two equal groups: Group 1 were normal candidate women under 40 years old has regular menstrual cycles (21-35 days), fertile (at least one natural pregnancy carried to term), and serum FSH was less than $10 \mathrm{mlU} / \mathrm{ml}$. Group 2 were premature ovarian oailure who aged under 40 years with absence of spontaneous menstrual bleeding for more than 12 months, serum estradiol level less than $25 \mathrm{pg} / \mathrm{ml}$, and serum FSH was level more than $40 \mathrm{mlU} / \mathrm{ml}$. All patients in this study were subjected to detailed history, general and local examination and laboratory study (FSH and E2 serum AMH level and serum lead level).

Lead was measured in blood after collection by Graphite Furnace Atomic Absorption (GFAAS) based on a method described by Amiri and Amini (2012), and AMH was measured in serum by ELIZA based on a method described by Hampl et al., (2011).

Statistical analysis: Data was collected, coded, and double entered into Microsoft Access and data analysis was performed using SPSS software version 18 under windows 7.Simple descriptive analysis in the form of numbers and percentages for qualitative data, and arithmetic means as central tendency measurement, standard deviations as measure of dispersion for quantitative parametric data, and inferential statistic test: For quantitative parametric data: Independent student's ttest used to compare measures of two independent groups of quantitative data For qualitative data, Fisher's exact test to compare two of more than two qualitative groups, and Bivariate correlation test to test association between quantitative variables. The level $\mathrm{P}<0.05$ was 
considered the cut-off value for significance.

\section{RESULTS}

All POF candidates were married, 30 patients $(60 \%)$ were from rural areas, while 20 patients $(40 \%)$ were from urban areas. Mean standard deviation and range of the age were $26.5 \mathrm{yrs}, 5.8$ and 18-39 yrs respectively (Table1).

Table (1): Demographic characters of the POF women.

\begin{tabular}{|l|l|l|}
\hline Variables & Characters & N (\%) \\
\hline Marital status & Single & $0(0 \%)$ \\
\hline & Married & $50(100 \%)$ \\
\hline Residence & & \\
\hline & Urban & $20(40 \%)$ \\
\hline & Rural & $30(60 \%)$ \\
\hline \multirow{2}{*}{ Age } & 26.4 yrs(mean), +/-5.8(SD), & \\
& $18-39 y r s($ range $)$ & \\
\hline
\end{tabular}

According to the parity, there was a statistically significant difference between case and controls with p-value $<0.001$. The multipara women were $50(100 \%)$, and $22(44 \%)$ in the control group and the case group respectively. The nullipara women were 0 and $28(56 \%)$ in the control group and the case group respectively (Table 2 ).

Table (2): The parity among cases and controls.

\begin{tabular}{|l|c|c|c|c|c|}
\hline \multirow{2}{*}{ Garity } & \multicolumn{2}{|c|}{$\begin{array}{c}\text { Control } \\
(\mathbf{n = 5 0})\end{array}$} & \multicolumn{2}{c|}{$\begin{array}{c}\text { case } \\
(\mathbf{n = 5 0})\end{array}$} & \multirow{2}{*}{ p-value } \\
\cline { 2 - 5 } & $\mathbf{N o .}$ & $\mathbf{\%}$ & $\mathbf{N o .}$ & $\boldsymbol{\%}$ & \\
\hline Nullipara & 0 & 0 & 28 & $56 \%$ & \multirow{2}{*}{$<\mathbf{0 . 0 0 1}$} \\
\hline Multipara & 50 & $100 \%$ & 22 & $44 \%$ & \\
\hline
\end{tabular}

As regards to age, there was no statistically significant difference between cases and controls with p-value 0.5. On the other hand, there was a statistically significant difference between cases and controls with $\mathrm{p}$-value $<0.001$. As FSH level and plasma lead levels were with high mean among cases, and AMH with high mean among controls. The mean
FSH was $4 \mathrm{mlU} / \mathrm{ml}$ and $52.1 \mathrm{mlU} / \mathrm{ml}$ in controls and cases respectively. The mean $\mathrm{AMH}$ was 1.1 and $0.52 \mathrm{ng} / \mathrm{ml}$ (normal range: $0.5-25 \mathrm{ng} / \mathrm{ml}$ ) in controls and cases respectively. The mean plasma lead was 10 and $4.1 \mathrm{ug} / \mathrm{dl}$ (normally up to $20 \mathrm{ug} / \mathrm{dl}$ ) in controls and cases respectively (Table $3)$. 
Table (3): Comparison of age and basal hormonal profile FSH, AMH and Lead among cases and controls.

\begin{tabular}{|l|c|c|c|c|c|}
\hline \multirow{2}{*}{ Parameters } & \multicolumn{2}{|c|}{ Croups } & \multicolumn{2}{c|}{ Controls (n=50) } & \multicolumn{2}{c|}{ Case (n=50) } & p-value \\
\cline { 2 - 6 } & Mean & SD & Mean & SD & \\
\hline Age & 27.5 & 5.7 & 26.4 & 5.5 & 0.5 \\
\hline FSH & 4 & 1.2 & 52.1 & 25 & $<\mathbf{0 . 0 0 1}$ \\
\hline AMH & 1.1 & 1 & 0.52 & 0.2 & $<\mathbf{0 . 0 0 1}$ \\
\hline Plasma Lead & 4.1 & 1.7 & 10 & 3.6 & $<\mathbf{0 . 0 0 1}$ \\
\hline
\end{tabular}

Among different residences, there was statistically significant difference between them with $\mathrm{p}$-value $<0.001$, plasma lead level among cases with high mean among rural residence. The mean plasma lead level was 7.6 and $11.4 \mathrm{ug} / \mathrm{dl}$ among urban and rural cases respectively (Table 4).

Table (4): Comparison of plasma lead level in different residence among cases.

\begin{tabular}{|l|c|c|c|c|c|}
\hline \multirow{2}{*}{ Residence } & \multicolumn{2}{|c|}{ Urban $(\mathbf{n}=\mathbf{2 0})$} & \multicolumn{2}{c|}{ Rural (n=30) } & \multirow{2}{*}{ p-value } \\
\cline { 2 - 5 } Parameters & Mean & SD & Mean & SD & \\
\hline Plasma lead level & 7.6 & 1.4 & 11.4 & 3.8 & $<\mathbf{0 . 0 0 1}$ \\
\hline
\end{tabular}

According to correlation between AMH level with age, FSH and lead among controls, there were statistically significant negative correlations between AMH level and each of age and FSH (r0.8.p<0.001, r-0.8; p<0.001) respectively, and there was no statistically significant correlation between AMH level and plasma lead with p-value 0.06. On the other hand, among cases there was high statistically significant negative correlation between AMH level with FSH with $\mathrm{p}$-value $0.001(\mathrm{r}-0.5 ; \mathrm{p}=0.001)$, and there was no statistically significant correlation between AMH level with age and plasma lead with p-value 0.1 and 0.4 respectively (Table 5).

Table (5): Correlation between AMH level with age, FSH and lead among controls and cases respectively.

\begin{tabular}{|l|c|c|}
\hline AMH $(\mathbf{n}=\mathbf{1 0 0})$ & $\mathbf{R}$ & p-value \\
\hline Controls & & \\
\hline Age & -0.8 & $<\mathbf{0 . 0 0 1}$ \\
\hline FSH & -0.8 & $<\mathbf{0 . 0 0 1}$ \\
\hline Lead & -0.2 & 0.06 \\
\hline Cases & & \\
\hline Age & 0.2 & 0.1 \\
\hline FSH & -0.5 & $\mathbf{0 . 0 0 1}$ \\
\hline Plasma lead level & -0.12 & 0.4 \\
\hline
\end{tabular}

According to correlation between plasma lead level with age, FSH, and $\mathrm{AMH}$, among controls, there was no statistically significant correlation between plasma lead level with age, $\mathrm{FSH}$, and $\mathrm{AMH}$ level with p-value $(0.92,0.83$ and 0.61 ) respectively. On the other hand, among cases, there was no statistically significant correlation between plasma lead level and age, FSH, and AMH level with p-value $(0.72,0.11$ and 0.41$)$ respectively (Table 6). 
Table (6): Correlation between plasma lead level with age, FSH, and AMH among controls and cases respectively.

\begin{tabular}{|l|c|c|}
\hline \multicolumn{1}{|c|}{$\begin{array}{r}\text { Plasma lead level } \\
(\mathbf{n = 5 0})\end{array}$} & $\mathbf{R}$ & p-value \\
\hline Parameters & & \\
\hline Controls & 0.03 & 0.92 \\
\hline Fge & 0.05 & 0.83 \\
\hline AMH & -0.08 & 0.61 \\
\hline Cases & & \\
\hline Age & -0.13 & 0.72 \\
\hline FSH & 0.23 & 0.11 \\
\hline AMH & -0.13 & 0.41 \\
\hline
\end{tabular}

\section{DISCUSSION}

Premature ovarian insufficiency (POI), also known as premature ovarian failure $(\mathrm{POF})$, is the condition when women experience early menopause. It is defined as ovarian failure before age 40 years (which is two standard deviations below the age of normal menopause) (Mann et al., 2012). In infancy, the FSH levels are greater than the levels reached during the normal adult menstrual cycles, decreasing to low levels usually by one year, but sometimes later, LH levels are in the range of lower adult levels, this early activity is accompanied by inhibin levels comparable to the low range observed during the follicular phase of the menstrual cycle (Andersen et al., 2010). $\mathrm{AMH}$ is initiated as soon as primordial follicles are recruited to grow into small pre-antral follicles and its highest expression is observed in pre-antral and small antral follicles (Dunlop and Anderson, 2014).

$\mathrm{AMH}$, produced by the granulosa cells of small growing follicles, inhibits initial follicle recruitment and FSH-dependent growth and selection of pre antral and small antral follicles (van Houten et al.,
2010). Lead is stored in soft tissue; autopsy studies show the liver to be the largest repository of soft tissue lead (33\%), followed by kidney cortex and medulla, pancreas, ovary, spleen, prostate, adrenal gland, brain, fat, testis, heart and skeletal muscle. Levels of lead in soft tissue appear to be relatively constant during life, despite a fairly high turnover rate (S Sharma et al., 2011). The present study shows that there is high statistically significant difference between cases and controls as regards to AMH with pvalue $<0.001$ with high mean among controls.

La Marca et al. (2010) supports the hypothesis that in women with hypergonadotrophic amenorrhea (POF) serum AMH levels are very low or undetectable, also hypothesized that the determination of serum AMH levels in POF patients could help in evaluating the persistence of follicles and possibly of the fertility potential and in some patients could also help in clarifying the mechanisms of ovarian dysfunction. Hagen et al. (2010) in cross sectional study of young girls with Turner Syndrome were investigated which factors 
had the highest predictive value for finding follicles, the most powerful were the presence of $46 \mathrm{XX} / \mathrm{XO}$ chromosomal mosaicism, serum FSH levels below 11 $\mathrm{mlU} / \mathrm{ml}$ and serum AMH levels $>0.28$ $\mathrm{ng} / \mathrm{ml}$. AMH may therefore have a role in the diagnostic work-up and fertility counseling of patients with Turner Syndrome. In the present study there is statistically significant negative correlation between AMH and FSH with p-value $<0.001$ among cases and controls.

Freeman et al. (2012) reported that the reproductive ageing related to changes in the hypothalamic-pituitary-ovarian axis associated with physiological and endocrine changes. One of the earliest signs of reproductive ageing is the FSH rise observed throughout the menstrual cycle, but most prominently noted in the early follicular phase of older ovulatory women. The physiological mechanisms behind the FSH rise are not completely understood, but probably involve decreased negative feedback (lower inhibin B secretion) from the diminishing number of pre-antral and early antral follicles in older reproductive aged women associated with decreased AMH level which secreted by the granulose cell of the pre-antral follicles.Our study shows that there is statistically significant negative correlation between AMH and age with p-value <0.001 among controls but not among cases.

La Marca et al. (2010) demonstrated that AMH may constitute an important measure of ovarian reserve as serum AMH level fall throughout the reproductive life and the level become undetectable after spontaneous menopause. Van Helden and Weiskirchen
(2017) was suggested that AMH levels were measured and used to determine an estimate of mean AMH as a function of age. It was found that there was good conformity between the observed distribution of age at menopause and that predicted from declining AMH levels. Our study shows that there is statistically significant difference between different parity with $\mathrm{p}$-value 0.01 as regards to AMH level with high mean among multipara group.

Freeman et al. (2012), in a prospective cohort study, showed that women who have given birth to more children are likely to have significantly higher AMH levels. These mean that women that having a high $\mathrm{AMH}$ is associated with a higher age at menopause.

Also, our study showed that there was a statistically significant difference between case and controls. As regards to plasma lead level with high mean among the cases, this study was in agreement with Qureshi et al. (2010).

Sharma and Bhattacharya (2014) concluded that Animals have shown that low levels of lead accumulation in the ovaries could impede folliculogenesis . A low Lead concentration in the mice ovary caused dysfunction of folliculogenesis with fewer primordial follicles and an increase in atretic antral follicles.

Qureshi et al. (2010) noted that ovary of lead treated animals showed damaging pattern in its structure and distribution of various components when compared to control. There was an evident damage in germinal epithelium, cortex and inner medullary region. Lead treated ovary showed damage in different types of developing follicles and various ovary 
components, i.e. germinal epithelium, cortex and inner medullary region. The lead affects the follicle and the extent of damage increase with the concentration of lead. Theca cells may also be a major target for heavy metal injury. Lead treated animals showed reduced number of primordial follicles, the granulosa cells gathered in the centre of the follicle and oocyte was not apparent and marked increase in atretic follicles. The study shows that there is statistically significant positive correlation between plasma lead level with FSH with p-value $<0.001$ among the study group.

Sharma et al. (2013) suggested that exposure of the ovary to heavy metals can directly cause ovarian failure by extensive follicular destruction. This targeting can result in the loss of ovarian steroid hormones and ultimate disruption of neuroendocrine feedback causing increased levels of FSH and LH. Our study also shows that there is statistically significant difference as regards to parity with p-value $<0.001$ between POF cases and controls with low parity among cases.

The association between parity and preterm ovarian failure was limited to sporadic cases of preterm ovarian failure (i.e. women without a family history of preterm ovarian failure), and disappeared when patients with familial preterm ovarian failure were considered separately, these women having a similar number of pregnancies. A possible explanation is that patients with a history of familial preterm ovarian failure may pay more attention to their reproductive patterns: they are aware of the earlier age of their relatives at menopause and as a consequence, tend to conceive earlier (Torrealday et al., 2017).

Finally, there was a statistically significant difference between different residence with $\mathrm{p}$-value $<0.001$ as regards to Plasma lead with high mean among rural. This difference can be attributed to the life style, the socioeconomic status or possible different surrounding environments.

A larger sample of population is needed to determine the AMH and Plasma lead in cases with premature ovarian insufficiency.

\section{CONCLUSION}

The majority of cases are presented after marriage may be due to lack of awareness before marriage about reproductive health. High prevalence of Premature Ovarian Failure in the poor rural areas arouses attention to importance of improvement of the reproductive health care. In the present study measurement of basal day 3 FSH has a highly significant difference between the two studied groups with high mean among the case group. The Anti Mullerian Hormone showed highly significant difference between the cases of premature ovarian insufficiency and the control group. Moreover AMH is a good marker for ovarian reserve and ovarian response for gonadotropins simulation. Chronic exposures to heavy metals specially lead affecting the ovarian function and impairment in folliculogenesis which increasing the incidence of POF especially in rural area due to the low socioeconomic status. 


\section{REFERENCES}

1. Amiri $M$ and Amini $R$ (2012): $A$ comparison of blood-lead level (BLL) in opium-dependant addicts with healthy control group using the graphite furnace/atomic absorption spectroscopy (GF-AAS) followed by chemometric analysis. Iranian Red Crescent Medical Journal, 14(8), 488.

2. Andersen CY, Schmidt KT, Kristensen SG, Rosendahl M, Byskov AG and Ernst E (2010): Concentrations of AMH and inhibin-B in relation to follicular diameter in normal human small antral follicles. Human Reproduction, 25( 5):1282-1287.

3. Dunlop CE and Anderson RA (2014): The regulation and assessment of follicular growth. Scandinavian Journal of Clinical and Laboratory Investigation, 74 (244):13-17.

4. Ebrahimi $M$ and Akbari Asbagh $F$ (2011): Pathogenesis and causes of premature ovarian failure: an update. Int $\mathbf{J}$ Fertil Steril., 5(2):54-65.

5. Flora SJS, Pachauri V and Saxena G (2011): Arsenic, cadmium and lead. In: Gupta RC (ed) Reproductive and Developmental Toxicology. Pbl. Academic Press, New York, 33:415-438.

6. Freeman EW, Sammel M, Lin $H$ and Gracia CR (2012): Anti-Mullerian Hormone as a Predictor of Time to Menopause in Late Reproductive Age Women. The Journal of Clinical Endocrinology \& Metabolism, 97 (5):1673-1680.

7. Hagen CP1, Aksglaede L, Sørensen K, Main KM, Boas M, Cleemann L, Holm $\mathrm{K}$, Gravholt $\mathrm{CH}$, Andersson AM, Pedersen AT, Petersen JH, Linneberg A, Kjaergaard $S$ and Juul A (2010): Serum levels of anti-Müllerian hormone as a marker of ovarian function in 926 healthy females from birth to adulthood and in 172 Turner syndrome patients. A.J Clin Endocrinol Metab, 95(11):5003-10.

8. Hampl R, Šnajderová $M$ and Mardešić T (2011): Antimüllerian hormone (AMH) not only a marker for prediction of ovarian reserve. Physiological Research, 60 (2): 217-23.

9. Jankowska K (2017): Premature ovarian failure. Prz Menopauzalny, 16(2):51-56.

10. La Marca A, Sighinolfi G, Radi D, Argento C, Baraldi E, Artenisio AC, Stabile G and Volpe A (2010): AntiMüllerian hormone (AMH) as a predictive marker in assisted reproductive technology (ART). Hum Reprod Update, 16(2):113-130.

\section{Mann E, Singer D, Pitkin J, Panay N} and Hunter $M \quad S \quad$ (2012): HunterPsychosocial adjustment in women with premature menopause: a crosssectional survey. Climacteric Journal, 15(5):481-489.

12. Okeke T, Anyaehie $U$ and Ezenyeaku $C$ (2013): Premature menopause. Annals of Medical and Health Sciences Research, 3(1):90-95.

13. Qureshi N, Sharma R, Mogra $S$ and Panwar K (2010): Ovary of lead treated animals showed damaging pattern in its structure and distribution of various components when compared to control. Journal of Herbal Medicine and Toxicology, 4(1):89-95.

14. Sharma S, Sharma V, Paliwal $R$ and Pracheta $R$ (2011): Lead toxicity, oxidative damage and health implications review. International Journal for Biotechnology and Molecular Biology Research, 2(13):215-221. 
15. Sharma DN and Bhattacharya $L$ (2014): Role of vitamin $\mathrm{e}$ on antifolliculogenesis effects of lead acetate on diameter of follicles containing ovarian tissue of swiss albino mice G.J.B.A.H.S, 3(1):322-325.

16. Sharma R, Panwar K, Barber I and Purohit A (2013): Lead toxicity and postnatal development of ovary. International Journal of Pharmaceutical Sciences and Research, 4(4):1575.

17. Sunil K (2011): Occupational, Environmental and Lifestyle Factors Associated With Spontaneous Abortion. Reproductive Sciences Journal, 18 (10): 915-930.
18. Torrealday $S$, Kodaman $P$ and $P a l ~ L$ (2017): Premature Ovarian Insufficiency an update on recent advances in understanding and management. F1000Res, 2(6):2069.

19. Van Helden $J$ and Weiskirchen $R$ (2017): Age-independent anti-Müllerian hormone (AMH) standard deviation scores to estimate ovarian function. European Journal of Obstetrics \& Gynecology and Reproductive Biology, 213:64-70.

20. Van Houten EL, Themmen AP and Visser JA (2010): Anti-Müllerian hormone (AMH): Regulator and marker of ovarian function. Annales d'Endocrinologie, 71(3):191-197. 


\section{العلاقة بين مستوى الرصاص ومثبط هرمون موللر بالدم فى المى المئ

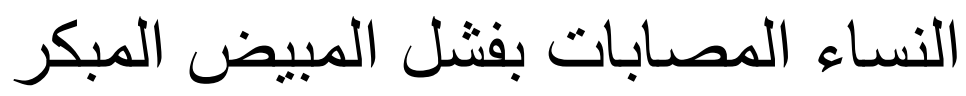

يحي عبدالسلام وفا، السيد محمد طه، عبد الرؤوف عبد الرووفف أبو نار، عطية أحمد

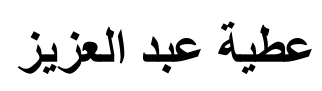

قسم امراض النساء والتوليد،كلية الطب، جامعة الازهر

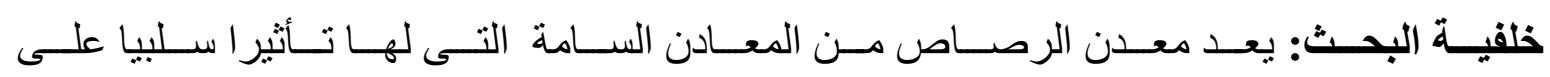

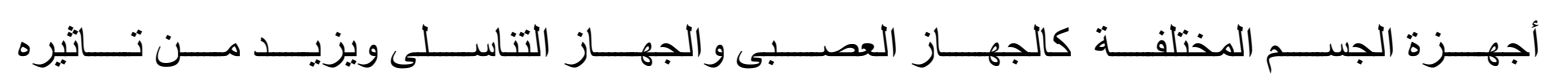

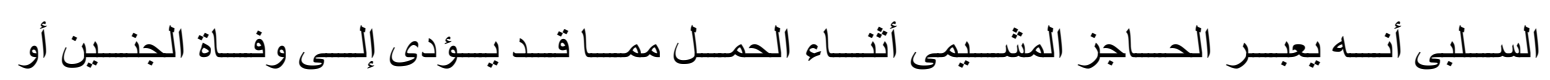
الو لادة المبكرة أو قلة وزن الجنين.

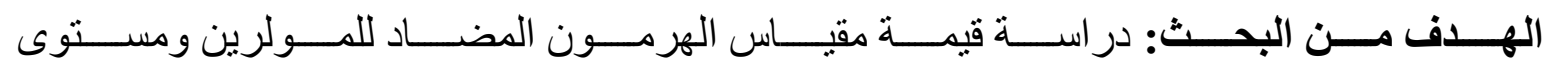

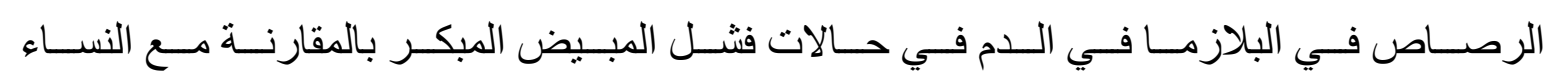

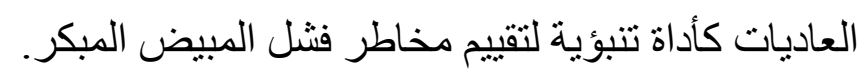

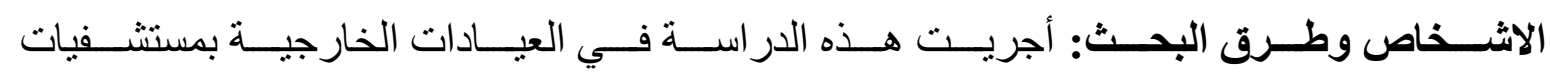

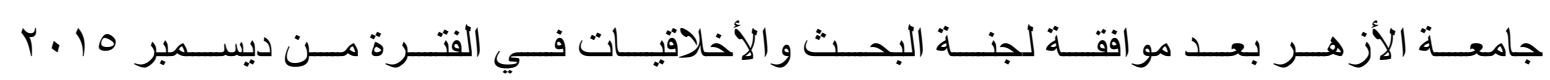

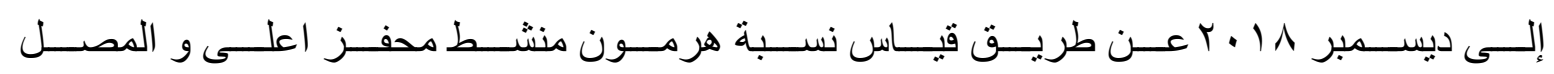

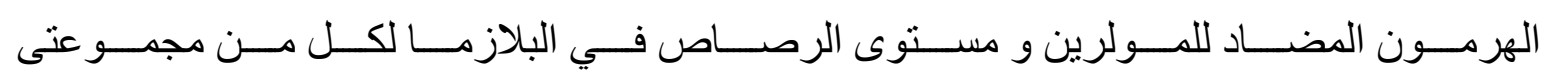
البحث:

المجموعة الاولى: شملت . ـ امر أة مصابة بمرض فثل المبيض المبكر. المجموعة الثانية: شملت .0 امر أة أخرى طبيعية غير مصابة بالمرض.

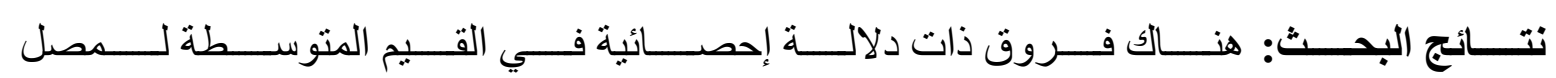

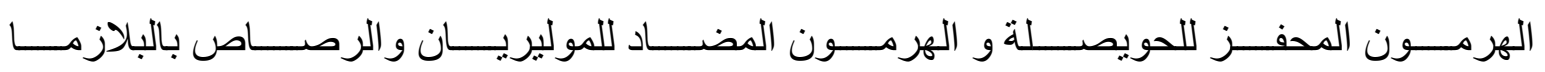
في مجمو عة فثل المبيض المبكر مقارنة مع مجمو عة التحكم.

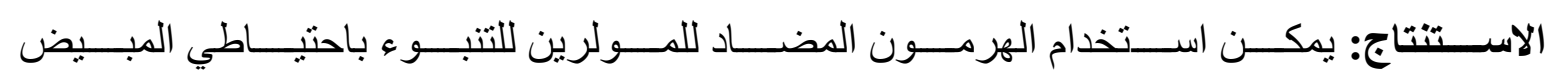

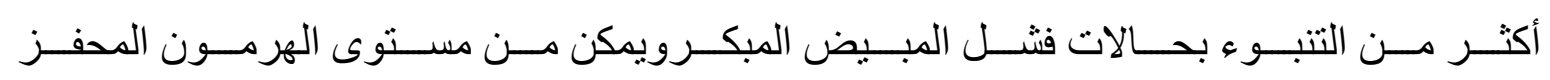




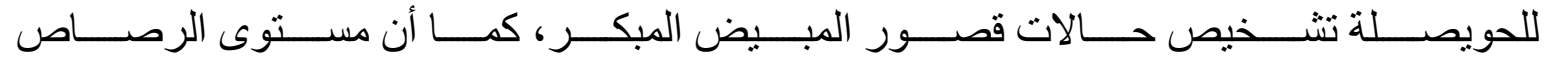

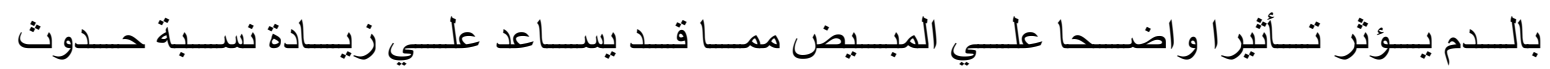
الفثل المبكر للمبيض، ولكن هذا المجال لا يز ال يحتاج الي مزيد من البحث.

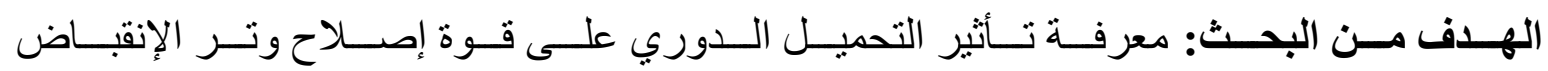
بإستخدام خياطة تانج ذات الست خيوط بشكل تجريبي.

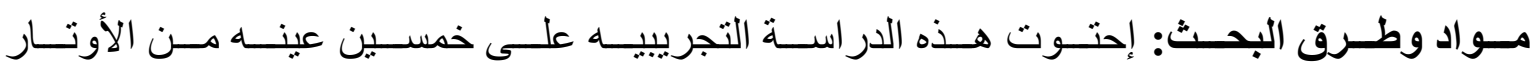

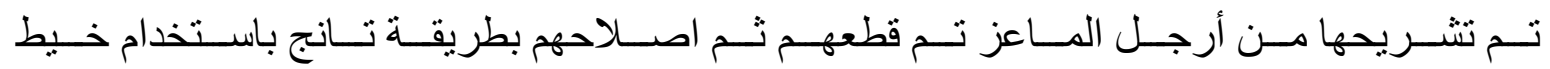

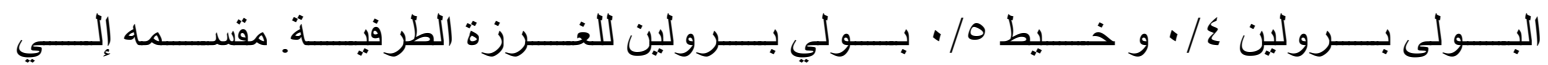

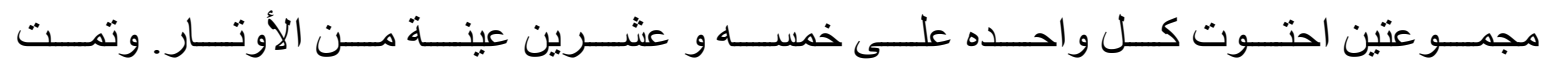

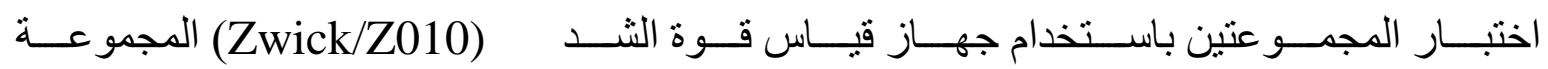

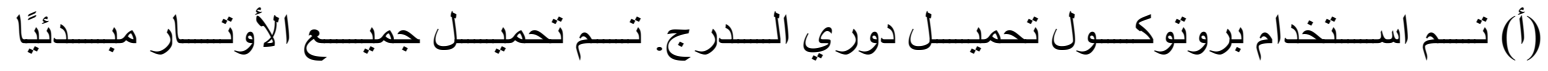

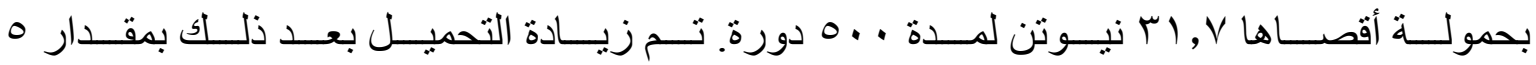

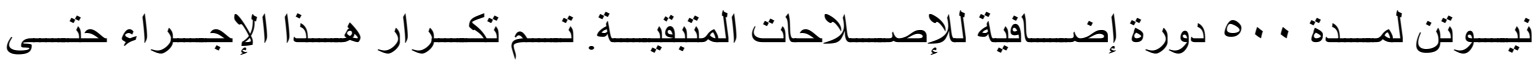

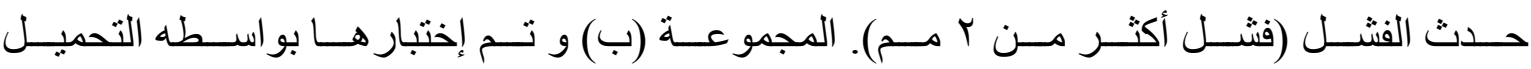
المستمر

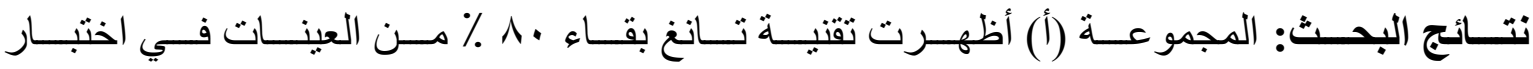

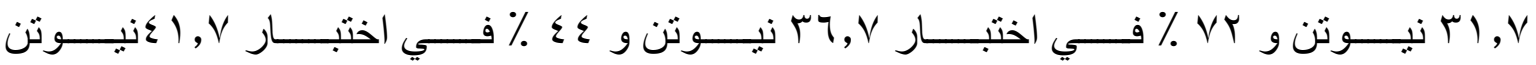

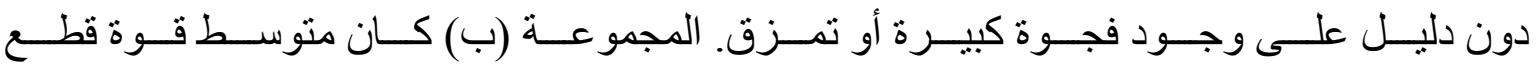

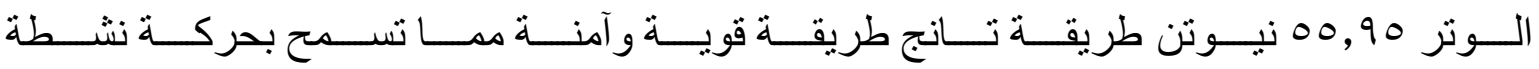

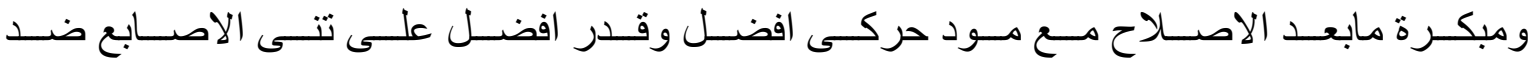
مقاومة.

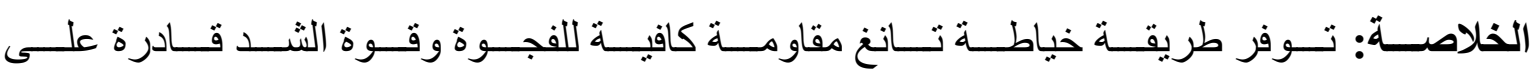

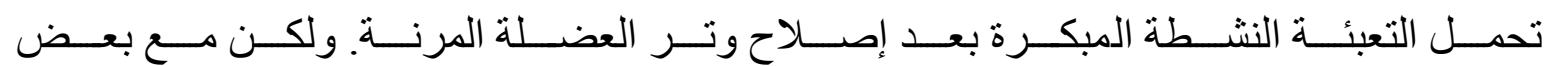

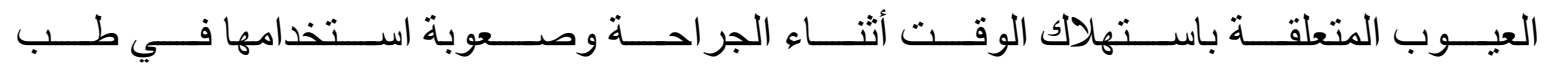
الأطفال و الأوتار الصغيرة. 